\title{
Wútùwútù Yáákí ${ }^{1}$
}

\author{
Ọlábíyi Babalọlá Yáî \\ Department of Linguistics and African Languages \\ Obbáfẹ́mi Awólọ́wọ̀ University, Ilé-Ifẹ̀ \\ Ọșun State, Nigeria.
}

Wútùwútù yáákí;

Wútùwútù yámbèlé;

Ká súré pátápirá,

Ká fệwù àlààrì fọnkun àmódi; ${ }^{3}$

Esẹ Ifá yìi jệ ộkan nínú àwọn ifá ńláńlá tí a fà yọ kúrò nínú Òtúá Méjì. Méjì ni àwọn onímọ̀-èdè Yorùbá tó ti yẹ ẹsẹ Ifá wò fínífíní pẹlú ijìnlẹ ìmò òde òní nípa èdè tí a ń pè ní lìngúísítíkì. Ẹni àkọ́kộ, Ọgbẹ́ni ’Wándé Abímbộlá la ẹsẹ Ifá sí ọ̀nà mẹjọ. ${ }^{4}$ Olátúndé Ọlátúnjí ni ẹnì kejì; òun pín ẹsẹ Ifá sí ìoộrí méje. ${ }^{5}$ Gẹegẹ bí a ó șe rí i ní ìsàlẹ (ẹ wo àlàyé 2), àwọn àyệwò méjèèjì tí a dárúkọ wọ̀nyí pọoọ́ léra. Nínú àdìtú wa yî́, ètò ẹsẹ Ifá onídàáméje ni a ó mùú lò nítorí pé ó dà bí ẹní bá ẹsẹ Ifá yî́ mu jù lọ. Nínú ìdá èkiíní (İlà 1 dé 8 ), a lè pín àwọn gbólóhùn ibẹ̀ sí orísiìi mệta.

1 Wọ́n kọ́kọ́ tẹ àpilệkọ yìi jáde nínú ìwé àtìgbàdégbà Yorùbá tíi ṣe jọnnà Egbẹe Onímọ̣ ède Yorùbá ti Nigeria ni ọdún 1976.

2 Òǹọ̀wé yìi ti di olóògbé báyìí.

3 Ẹkúnrẹeré ẹsẹ Ifá náà wà ní Àfikún II ní ìparí àpilẹ̀kọ yî́.

4 'Nearly all ese Ifá have a maximum of eight main parts: (i) name(s) of the Ifá priests involved in a past divination, (ii) name(s) of the client(s) for whom the divination was performed, (iii) reason for the divination, (iv) the instruction of the Ifá priest(s) to the client(s) after the divination (v) whether or not the client complied with the instructions, (vi) what happened to the client(s) after he carried out or refused to carry out the instructions, (vii) the reactions of the client(s) to the joy or sorrow that resulted from the process of divination, (viii) the moral from the story as a whole." Láti inú tísíisì Wande Abimbọla, $A n E x$ position of Ifá Literary Corpus, University of Lagos, 1969, ni a ti fa àwọn àyọlò yìi kúrò.

5 (i) citation, (ii) presentation of the client, (iii) Ifá's commands, (iv) reaction of the protagonist, (v) result of the protagonist's reaction, (vi) intra-structural recapitulation (optional), (vii) general comments. Láti inú tísíìì Ọlátúndé Ọlátúnjí, Characteristic Features of Yorùbá Oral Poetry, University of Ibadan 1971, ni a ti fa àwọn àyọlò yìi kúrò. 
Ìlà láti 2 fi ara jọ ara. Bí a bá sì là wộn wò, a ó rí i pé sítírọ́kíṣọ kan náà ni wộn ní. İlà 3 àti 4 ní sítírộkísọ oní-kí. Bí ó tilẹ jẹe pé ộọ̣ tí a sọ nínú ìà méjì wọ̀nyí yé ni láìsí àníàní, a lè sọ síbẹ pé wộn șe bí ẹni șàjèjì sí gírámà Yorùbá ní ọ̀nà méjì. Àkộkọ́, ipò tí pátá-pirá wà ní ìlà 3 yìi kì í șe ipò tí a sáábà máa ń rí i. Kí a fi pátápirá tẹ lé fáàbù kò wộpọ̣. Bí ó bá șe ẹyán ọ̀rọ̀ míràn gẹgẹ bí tètè ni a rí ní ipò yî́ ni kì bá tí sí ìyànilệnu.

Lộnà kejì ẹ̀ẹ̣, bí a bá fi gírámà Yorùbá wọn àpapọ 1 ìlà 3 àti 4, a lè sọ pé gbólóhùn tí ó là wộn já kò pé, kò sì kún. Nítorí pé bí a bá fi kí bẹ̀rẹ gbólóhùn kan, a gbọdọ fi ìdajìi gbólóhùn míràn gbè é lệsẹ̀ ni, eléyì ìbáà șe gbólóhùn oní-kí bákan náà tàbí irú gbólóhùn tàbí kílọọ̣sì oní sítírộkísọ míràn. Fún àpẹrẹ:

1. kí a ké sí wọn ki a tóó lọ (İyẹn kò yẹ ọmọ lú àbí)

2. kí á lọ jalè ní ilé àna ẹni (ǹjẹe èyí ha dára bí)

\section{Nìjẹ a lè ka ìlà 3 àti 4 sí ìsẹ́kù gbólóhùn?}

Gbólóhùn kan ṣoṣo náà ló la àwọn ìlà 5 dé 8 já. Gbólóhùn ọhún sì ní kí nínú. Șùgbọ́n a kò lè șaláìșàkíyèsí pé àtò-ódì ni a to àwọn àmúlù inú gbólóhùn yí. Dípò bí $+\mathrm{NP}^{6}, \mathrm{NP}+$ bí ni a rí níbẹ.. ${ }^{7} \mathrm{NP}$ èyí tíí șe orúkọ ni a kọ́kọ́ fi bẹ̀rẹ gbólóhùn yí láti fi han pé ẹọ ọ̀rọ̀ yí (lékèélékèè) jẹe kókó ọ̀ọ̣ nínú gbólóhùn náà àti nínú gbogbo ewì ọhún pàápàá. Njẹ̣ kí a lè baà ya orúkọ (lékèélékèé) sí ọtọ̀ ni babaláwo akéwì yí șe fi í sí ìbẹ̀rẹ gbólóhùn náà kí ó tó wáá fi gbólóhùn oní-bí parí rẹ̀.

Ilà 5 yóò dá wa padà sệhìn díẹ láti tún ìlà 1 àti 2 yẹ̀ wò. Sítírọ́kíṣọ rẹ̀ ran ni lọ́wọ́ láti le fún àwọn ìlà 1 àti 2 ní ìtúmọ pípé. Lóòótọ, ọoọ dún-bí-mo-ti-dún (onomatopoea) ni wọ́n láisí àníàní; sùgbộn a tún lè fún wọn ní itúmọ míràn. A kò lè sọ wí pé èèyàn ń wá òfinntótó ọ̀rọ̀ tàbí pé a ń wá ohun tó ń bẹ lápòo șòkòtò lọ sí Sókótó tí a bá wútùwútú yáákí sí ẹddà (transform):

A kò sí déédé la ọ̀oọ yí báun. İdí abájọ ni pé, lákọoọoộ, nínú ọ̣pọ̀lọpọ̀ ẹsẹ Ifá ni a ti ń rí gbólóhùn tí sítírọ́kíṣọ wộn ní ọ̀ọ̀-dún-bí-mo-ti-dún bẹẹè, tàbí idiofóònù tí í șe ọmọ ìá rẹ̀, tí wọn sì fi awo, ọmọ, ló día fún... àti bẹẹe bẹẹ lọ, so pọ mọ́ ẹyọ ọ̀rọ tó kù. Fún àpẹẹrẹ:

1. İtarúkú, awoo wọn lóde ìtarúkú;

Ìtarùkù, awo Ìtarùkù;

Rùkùrúkù-tataata (İrosùn Méjì Ẹsẹ 1) ${ }^{8}$

6 A kò lè ya gírámà Yorùbá sí ọ̣tọ̀ nítorí pé Lìngúísítíikì ti kọ́ wa pé ọ̣pọ̀lọpọ̀ ọ̀ọ̣ bíi fáàbù, bí orúkọ abl., ló kó gbogbo èdè pọ̀. Ėyí ló mú kí a máa fi orúkọ kan náà pè wọ́n kí á sì máa fi lệtà kan náà tộka sí wọn nígbà tí a kò bá fẹ́ pè wộn ní àpètán, bí ó tilẹ jẹ pé àwọn lệtà bí, Q, C tàbí V kò sí nínú àbídí Yorùbá.

7 Fún ẹ̀kúnrẹreẹ àlàyé, ẹ wo: Ayọ Bámgbóșé, A Grammar of Yorùbá, o.i. 62.

8 Abimbọla, İjìnlẹ Ohùn Ẹnu Ifá, Apa 1, İrosùn Méjì, ẹsẹ èkíní, o.i. 62. 
2. Keesekeese lẹ ti ńrí

Kààsàkààsà ḿbọ̀ lẹ́yìn

Kààsàkààsà baba a keesekeese. (Ọ̀bàrà Méji). ${ }^{9}$

Lọnnà kejì, wútùwútù àti lékèélèkèé kò șài fi ara jọ ara nípa sítírọ́kíṣọ wọn ní ọ̀nà fonọ́lọjìi Àwítúnwí ọ̀rọ̀ onísílébù méjì, tí wọn ní kọ́ńsónáṅtí méjì șùgbọ́n fáwệlì kan náà ni wọ́n ń șe: $\mathrm{C}_{1} \mathrm{VC}_{2} \mathrm{~V}$.

Bẹẹ gẹgẹe, lékèélékèe eye imọle dà bí gboùngboùn wútùwútù yámbèlé: A lè ka ìmọ́lẹ àti yámò̀é sí alákùdé ráímù.

Kín wáá ni àșeyìnwá àșẹyìnbọ̀ sítírộkíṣọ ìdá kiíní ẹsẹ Ifá yìi? Ó fi hàn ni pé babaláwo fẹeẹ fi yé ni pé oùn șẹ̦ẹ bẹ̀rẹ̀ ẹsẹ Ifá yìi ni o, șùgbọ́n ọ̣ọ̣ kù lệhìn tó pọ̀. Báun ni a lè túmọ ààbọ ọ̀rọ̀ tí ń bẹ lára sítírọkísọ oní-kí. Àti pé sítírókíṣ̣o gbólóhùn àwọn ìlà 6-7 tilẹ fi àwọ jọ àló àpamọ tí a ti fún ní itúmọ̀ tàbí ìdáhùn rẹ̀ kí a tóó pa á. Kódà gbólóhùn abájọ (protasis) tilẹ ni ètò ọ̀ọ̀ tí a tò sínú àwọn ìlà wọ̀nyí. Ní ộọ̣ kan, a tẹ́ní Ifá ni, à kòì tîi kì í, bẹeẹ ni ìjìnlẹ itúmọ ìdá kiíní ẹsẹ Ifá yî̀. Șé “mò $\boldsymbol{n} \boldsymbol{b} \boldsymbol{o} \boldsymbol{n}$ èe șe tán” náà ni àwọn akéwì fi í bẹ̀rẹ̀ ipa titun nínú ewì wọn, "ó dọ dẹdẹ niberẹ̣" sì ni èdè Ifá alára. ${ }^{10}$ Bí a bá fi ojú gírámà wò wọ́n, șe ló yẹ kí á kó ìdá 2 àti 3 pọ̣ fún àyẹ̀wò, nítorí pé șe ni babaláwo hun wọ́n pọ̀. Bẹẹ náà ló sì hun ìdá 3 àti 4 pọ̀ (ilà 9-18). Ara ìdá kẹrin ni ìà 12 í șe (ó sì rú u) İdá 3 tún bẹ̀rẹ̀ láti ìlà 13 dé 17 . Ėyí ni pé ìdá 3 kò fi bẹẹ lọ tààrà. Ní ìk fèlèku-fèlèjí ni akápọ náà kì í. Ó mòòkùn, ó tún sọ jáde bí ẹja omi ni. İdá 3 kọ́ kọ́ wọlẹ̣ lệhì ìlà 11 ó sì tún șẹ jáde láti ìlà 13 dé 18 . Ìlà 11 dúró fún odindin ọ̀ọ̀i ìlà 13 dé 18 odindi ọ̀ọ̀ là yíí sí wẹ́wệ. İbátan tó wà láàrin odindi àti è̀eé, ni irú ìbátan tí ń bẹ làárín wọn.

Àwọn ìlà 13 dé 17 tẹ́ ẹní aláwiítúnwí sílẹ salau. Bẹẹ̀ ni a sì gbin șẹ́gímà (Zeugma) sí àárín wọn (bẹ̀rẹ̀ láti ìlà 15). Sẹgímà yì șe pàtàkì fún ìsíisẹ ẹ̣ẹ Ifá yìi. A kò sàdéédé fo gbólóhùn " $k i$ " ru nínú àwọn ìlà 15,16 àti 17 . Ohun tí $\mathrm{o}$ mú babaláwo fo gbólóhùn yî́ ru ni pé àwọn orúkọ tí a fi șe àfikún fáàbù ịse nínú ìlà 15 dé 17 gùn ju àwọn ojúgbà wọn ti ìlà 13 àti 14 lọ. Àwọn orúkọ ti ìlà 15 dé 17 ní sílébù mẹ́rin, mẹta gẹgẹ́ bí wộn ṣe tẹ̀lé ara wọn (obídiẹ, ewúrẹe, ẹinlá) níbi tí ojúgbà wọn ní sílébù méjì péré (eku, ẹa). Èyí un ló jẹ kí sẹgímà tí à ń wí yiî́ lè wáyé. Àfikún fáàbù ịṣe kan șoṣo (rú) ni àwọn ìlà 14 dé 17 í șe. Sítírókíṣọ kan náà ni a ó sì rí nínú gbogbo àfikún wọnyí, èyí ni: Orí-Ẹyán (HQ). A sì tún lè tú Ėyán ọhún sí Q...Num + Adj (Ộọ iye àti ọrọ àpèjúwe). Mọfọ́lọjì òrọ àpèjúwe yìi ta kókó. Títú rẹ fi ẹọ ộọ méjì hàn ni: àfikún apá òsì (abi-, oni-) àti idiofóónù. Ìlà 17 nikan ló yapa nítorí pé èyán tirẹ ní tí nínú. Ní àkótán, sítírộkísọ ìdá 3 jọjú, ó sì pegedé. Ó wáá dà bí ẹni pé bí wộn șe ń tẹ̀ lé ara wọn un, ijóo rí-bí-mo-ti-rí, dà-bí-mo-ti-dà ló șá ń fa oníkálùkù ìà wọ̀nyẹn

9 Abimbọla, İjìnlẹ Ohùn Ẹnu Ifá, Apá 2, o.i. 110.

10 Abimbọla, İjìnlẹ Ohùn Enu Ifá, Apá 2, o.i. 57 
lẹesệ. Wọ́n bá ara wọn șe déédé, İdí nìyí tí àkọ́sórí wọn rọrùn láissi ìsọyè fún àti babaláwo àti ọggbệrí.

Ohùn ìtàn ni a fi sí ìdà kaàrún (ìlà 20 dé 68 ). Gbólóhùn gírámà tó tọ́ka sí àkókò ni àmì ohùn ìtàn yí: ighbà tí. Kí a lè baà mọ bí ìàn șe șe pàtàkì tó ní ìdá yìí; a ní láti șàkíyèsí pé ẹẹmeệà ni àmì yí (igbà tí) yọ jáde níbẹ̀. (A lè rí i nínú àwọn ìlà $21,23,28,35,53$ àti 62 ). Bí ó tilẹ jẹ pé ìdá yìi fi ara jọ ìtàn púpọo, tí a sì le tìtorí rẹ kà á sí ọ̀rọ gbẹrẹfu, yàtọ fún ohun ti a lè kà sí ewì, síbẹsíbẹ kò șaláìní ẹwà tirẹ̀. Ėyí hàn nínú sítírọ́kíṣọ rẹ̀. Àwọn ìlà tó bá ara wọn șe dédé ni babaláwo wáá fi dárá bí ilẹ bí ẹní níbí. Bẹẹ sá ni a le ka àwọn ìlà 19, 21, 23 àti àwọn tó tẹ̀ lé ọ́kọộkan wọn $(20,22,24)$ si. A tilẹ rí i pé gbólóhùn kan ṣoṣo náà ló kó àwọn ìlà tí a dárúkọ wọ̀nyí já láti òkè dé ilẹ̣. Sítírọ́kísọ àwọn ìlà tí a kọ́kọ dárúkọ ni: Àfikún nípa àsìkò-àpólà gbólóhùn olórúkọ-àpólà gbólóhùn onífáàbù, (Adjunct-NP-VP). Tí èkejì sì ni: àpólà gbólóhùn olórúkọ-Àpólà gbólóhùn onífáàbù-Àpólà gbólóhùn olórúkọ-Àpólà gbólóhùn onífáàbù-Àpólà gbólóhùn olórúkọ $(\mathrm{NP}-\mathrm{NP})$. Ìlà ikẹ́hìn ti ộwọ́ tí a mẹ́nu bà yí ya ara rẹ̀ sọ́tọ (ilà 24): NP kejì inú rẹ̀ gba èyán (èyí tí ìṣe ọmọ...ì̀à 25). İjìnlẹ ìtúmọ ẹ̀yán yî́ ń bọ lệhìn.

Kókó ọ̣oọ-bí-ìtàn, tí a sọ wí pé ó șe pàtàkì nínú ìdá 5 yií, láti ẹsẹ 36 dé 48 ló jọba sí. Ògédé wọn ni babaláwo fi ń pilẹ gbogbo ìlà ibẹ̣. "Wọn" yìi dúró fún àwọn èèyàn tí wọ́n ní ìpín nínú ohun tí ẹsẹ Ifá tọ́ka sí. Fáàbù ị̀e ni a fi tẹ̀lé gbogbo àwọn "wonn" wọ̀nyí. Nígbà míràn fáàbù ìse yií a ní àfikún, nígbà míràn ệwẹ̀ a le fẹ àfikún kù. İșíṣẹ ìdá yî́ yàtọ gidigidi.

Bẹeè náà sì ni ìșísẹ yí ní ijìnlẹ itúmọ̣: A ó rí í pé àwọn ìlà tí fáàbu ìșe wọn jẹ mọ́ iṣẹ́ tàbí ìse tó le gba ni lákòókò, gùn ju àwọn ìyókù lọ. Àwọn ìlà yií nìkan ló sì ní fáàbù aláfikùn. Gẹegẹ bí àpẹerẹ kí a fi àwọn ìlà 36 dé 41 wé ìlà 43 dé 45 wò.

$\begin{array}{ll}\text { Wọ agbádá náà } & \text { foríi kanlè } \\ \text { Wé gèlè náà sórí bàǹtùtù bantutu } & \text { dìde } \\ \text { Na igi mẹ́rin sílẹ̀ níbùú níbùú } & \text { kúnlẹ̀ } \\ \text { Kó sí ààin igi náà } & \text { nàró }\end{array}$

Șùgbọ́n șe ni àwọn ìlà tó ní fáàbù tó jẹ mọ́ ịṣe tí kò gba àkókò púpọ̀ kúrú: sàșà nínú wọn ló ní fáàbù tó gba àfikún; àti pé VP wọn tó tẹ̀ lé "wọn" kì í sábàá ní ju sílébù méjì lọ (forí kanlẹ̣, dìde, kúnlẹ̣, nàró).

Ìkadî̀ ètò sítírọ́kísọ yiî ni pé ị̀ísẹ rẹ̀ kọ́kộ wúwo ní ibẹ̀rẹ ìtàn yí; ìtàn ộhún kò gbésẹ̀ nílẹ bọ̀rọ̀. Șùgbộn bí a ti ń sún mọ òpin, bẹẹ ni ìsísẹ tún fi ń yá sí $i$, nítorí pé àwọn gbólóhùn fúyẹe sí i. İșísẹ wàá di ganran ganran nígbà tí iná ìtàn wá ńjó lọ sórí kókó. Ní ìdá 5 yî́ náà la rí ọ̣ọ̣lọpọ ìlá tí í mú ni dá ẹsẹ Ifá mọ̣ gẹgẹ́ bí: 
Ikú kò pa wọ́n,

Àrùn kò șe wọ́n.

tàbí pàápàá jùlọ:

Ọrúnmìlà kọ́ wọn ní dídá ọwọ́

Wọ́n mọ ọ́n dá... àti bẹẹ bẹẹ lọ

Àwítúnwí alákùdé ni akéwì fi hun aṣo ẹwà ẹsẹ Ifá yìi níbí. Kí á ma wulẹ tún șe àwáwí kan lórí ìdá kẹfà mọ́ nítorí pé àwítúnwí ìdá èkíní dé è̀kẹin ní í ṣe. Șùgbọ́n àwọn ìlà 82 dé 87 jẹ ìlà ẹlẹrìi ẹsẹ Ifá tó bẹẹ tí a kò lè fẹnu fò wọ́n ru. Nínú ìdá keje ni ẹse Ifá yìi ti gún. Àwítúnwí alákùdé tí a fi ộkan-kò-jọ̀kan ẹọ ọ̀ọ̀ parí ìlà wọn ló jọba níbẹ. Ìlà ìeẹhìn ló gùn jù lọ níbí nítorí pé àfikún fáàbù ní ẹyọ ọ̀rọ méjì (orúkọ àti ẹ̀yán) níbi tí àwọn ìlà tó șíwájú rẹ̀ kò tilẹ ní àfikún rárá. Gígùn ìà ìkẹìn yìi kò șàiní ìtúmọ gẹgẹ bí a ó ti rí i bí a bá tẹ síwájú. Ní àkótán, ní òpópó gírámà, ẹsẹ Ifá yìi dà bí ibú onírúnrú sítírộkísọo: Bí a ti ń rí oríșiîrísiiì àwítúnwí, bẹeẹ náà ni a bá sẹ́gímà, onírúnrú àșẹ́ku gbólóhùn, gbólóhùn tó fi ara jọ àlọ́, ibáà jẹ àpamọ tàbí ọ̀kanṣoṣo-bí-orógbó ni o, kò sí orúkọ tí a lè fi pè é tí kò ní bá a mu.

\section{İjìnlè İtúmọ̀ (Sè̀máńtíî̀i)}

Àpárá kó ìpín pàtàkì nínú àwọn ìjìnlẹ èdè tí ẹsẹ Ifá yìi ń fọ̀. Kódà ohùn àpárá náà ni babaláwo wa fi șíde. Ó sì fi bẹẹ fi ẹsìn mùsùlùmí șe ẹsín láti ìbẹrẹ dé òpin ẹsẹ Ifá yìi. Nígbà míràn, èdè àpárá yìi a hàn kedere sí ni; șùgbộn șe ni a ó họ ara ẹsẹ ộhún tí a ó tilẹ fệrẹẹ jệwọ ộbún kí a tóó lè mọ àpárá tí ń bẹ níbòmíràn tí a kò tilẹ pète rárá.

Ọnà pàtàkì kan tí a lé gbà bí a bá fẹeé fi nǹkan tàbí ẹnìan șe ẹsín ni pé kí a mú ọ̀ọ̀-dún-bí-mo-ti-dún lò bí a bá fẹeẹ sọ̀rọ̀ nípa ẹnìan tàbí nǹkan náà. Șé agbára káká náà ni a lè fi ka ọ̀rọ-dún-bí-mo-tí-dún kún ara èdè. Nítorí ní agbedeméjì èdè àwọn ọmọdé tàbí ohùn àwọn ẹranko àti èdè gidi ni àyè ộộ-dúnbí-mo-ti-dùn wà. Lílò tí a lò ó níbí (wútùwútù) fi hàn ni pé èdè bí ẹnà tàbí èdè àjèjì șá ni àwọn tí ń sọ ợọ wọnyí ń fọ̀. Kì í șe èdè gidi. Kí á rántí òwe Yorùbá tí ó lọ báyîi: “Bí n kò gbọ ègùn, mo sáà gbọ wọyọw wọyọ̣”. Wọ̀yọ̀wọ̀yọ àti wútùwútù, ọmọ ìyá ni wọ́n láìsí àníàní. Ǹjẹ gẹgẹ bí Ègùn ṣe lọ lẹnu àwọn Yorùbá, tí ó sì șe àjèjì sí èdè wọn, bẹẹ náà ni babaláwo fi n dá a lápàárá pé èdè tó $n$ jáde láti ẹnu àwọn mùsùlùmí kò yé ayé. A rí irú lílo ọ̀rọ̀-dún-bímo-ti-dún bẹẹ nínú ẹsẹ Ifá miíràn tó lọ báyií lórí èdè àwọn Tápà:

A díá fún Fátúsì

L'Éǹpe, nílé alété w’Ọya 


\section{Afèdì ọ̀kọ tẹlẹ fọ mọgàmògà. ${ }^{11}$}

İjìnlẹ àpárá náà ni a ó tùún rí nípa àwọn orúkọ mùsùlùmí tó jáde níbí. Șé wọ́n ní orúkọ a máa ro ni. A yan orúkọ mẹta wọ̀nyí ni, kì í șe pé a kàn dédé lò wọ́n láisí ìtúmọ. Wọn kì í șe orúkọ tó wọ́pọ̀ láàrín àwọn mùsùlùmí. A ó kìiyè sí wí pé sílébù ìkẹhìn àwọn orúkọ mẹetẹẹta wọ̀nyí jẹ́ fáàbù ní èdè Yorùbá, $b i$, tú, dù. Bí a ba sì darí gbogbo wọn jọ, tí a sì tún fi ìtúmọ oníkálùkù wọn wé ara wọn wò láìgbàgbé ẹ̀mí tó gun babaláwo wa kí ó tóó ki Ifá yî̀ (ẹmí Òtúrá Méji), a ó ri i pé àwọn fáàbù mẹtẹẹta lè fún wa ní kộkọ́rọ fún ệkúnrệeẹ itumọ̣ nípa ẹ̀gàn, odì àti ìjà tí ń bẹ láàrín ẹ̀sìn ti láéláé àti èyí titun. E sá jẹẹ kí á gbìyànjú kí a tú wọn wò:

Gáńmbín: $\quad$ Ọmọ (ẹsìn) tuntun tí a ti bi lệhìn ìgbà tí a ti gán ti láéláé lórí. Tàbí èyî́ tuntun rộpò (bí) èyî́ láéláé tó ti ń kú lọ.

Kàlìtú: A lè ka orúkọ yî́ sí ẹ̀dà gbólóhùn "Kò ní lè tú" Ėyií ni pé bí ìrókò (ẹsìn tuntun) șe ń sọ pé kó wó kó wó, bẹẹ̣ náà ni àràbà (ẹ̀sìn láéláé) ń șagbára láti fi ẹsẹ dúró șinșin.

Dáúdù: Ẹsìn tuntun ń du ipò ẹ̀sàn àdáyébá.

Èmí ìfinișẹlẹ́yà náà ló tún hàn nínú títò tí babaláwo to àwọn orúko mẹ́tẹeta, àní bi àwọn ọmọ Ợúnmìlà șe tẹ̀lé ara wọn. Dáúdù ni a fi șe àbíkẹ́hìn àwọn ọmọ Ộrúnmìlà. Bẹẹ ni a sì mọ pé nínú àșà Yorùbá, àkọ́bí ọmọ ní í jẹ́ Dáúdù. Njẹ́ nípa kí a mọoọmọ̣ lo ìtúmọ orúkọ ní òdì ni a ti lè rí ẹ̀mí ìinișệ̣́n. Bóyá nípa àtòódì tí akéwì wa to àwọn ọmọ mẹtẹệta wọ̀nyí, ó fẹé sọ fún wa pé șe ni ẹ̀sìn tuntun ń gbìyànjú láti da ẹ̀sìn àtijọ́ rú kí ó sì wá tún gbogbo nǹkan tò. Akéwì kò fi ẹgàn mọ níbi orúkọ nìkan. Nínú ìdá 4 , gbogbo ohun tí àwọn ọmọ mẹteẹẹta ń șe ló dá ệrín pa ni: Wọ́n wé gèlè (Kò tọ̀nà kí ọùnrin Yorùbá wé gèlè). Láti ìlà 40 dé 46, ohun tí àwọn ọmọ mẹẹẹẹta ń șe kò nídií, kò sì ní itúmọ̀; wộn dà bíi wèrè ("Baba wọn șá ń wò ni). Bẹeẹ ni wèrè kò sì șeé bí lọ́mọ. Șùgbọ́n wọ́n ni “ẹgàn kò póyin má dùn”. Babaláwo tó ki Ifá yií mọ̀ pé kò tọ́ kí òun fi ẹnu ẹ̀gàn lásán tẹe ẹ̀sìn ìmàle. Nítorí èyí láti ìjìnlẹ ọgoọn àti òye ni yóò wáá fi han ni pé òtítọ gidi ń bẹ nínú ọ̣ọ̣ àwàdà tí òun ti ń báa bọ. Ìlà tó kira jùlọ lộnà ibẹ un ni ìlà 8 : "A máa fi gbogbo ara kéwú eléwú kiri". İfọ̀rọ̀dárà tí babaláwo lò nínú ìlà yí gbayì. Ó șe bẹẹ fi òkò kan șoṣo pa ẹyẹ méjì. İtúmọ eyọ ọrọ keệwá yà sí méjì: A lè fi ọgbọ́n ògeere èdè tú u sí àkànpọo ộọ̀ méjì: a ó rií fáàbù kan àti orúkọ àfikún: kó + ewú. Bí a bá sì rò ó sí mộfímù kan ṣoṣo a ó rìi kéwú-ìwé arábíìì tí a fi a.b.d. lárúbááwá kọ.

Wọ́n fi bẹẹ̀ so àmì ogbó (ewú irun-funfun)...àmì nǹkan àtijọ́ tó ti rà, tí kò dára tí kò sì wúlò?...mọ́ ohun pàtàkì tí a lè fi dá ẹsìn ìmàle mọ̀ (kéwú, ìwé

11 Abimbọla, İjìnlè Ohùn Ẹnu Ifá, Apá 3, o.i. 41. 
mímọ́ àwọn mùsùlùmí). Pátápirá rẹ̀ ni pé a fẹeé mú ni gbàgbọ́ pé èsìn ìmàle ti dìkàsì. Șùgbọ́n etí nìkan kọ́ ni bababláwo fi ọ̀ràn lọ̣. Ojú náà ní ìpín tirẹ̀ níbẹ̀; èyí sì hàn nínú ìlà 8 . Șe funfun ni ewú gẹgẹ́ bí ệuù tí àwọn ìmọ̀le máa ń dà bora. Ṣùgbọ́n ní èrò babaláwo funfun ti ìmọ̀le kì í șe funfun lệlẹ́ tí ń ya nǹkan sí mímọ́ bí kò șe àmì nǹkan abàmì. Ó mú ni rántí ẹsẹ Ifá kan tó lọ báyìi:

Gbogbo orí àfín ewú

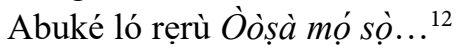

Lệhìn náà, "ewú eléwú" fi han ni pé ẹsìn ìmọ̀le kì í șe tiwa; ẹ̀sìn tí ó tilẹ le mú kí àwọn àjèjì tàbí àbùlẹdó le gàba lórí wa lọjộ iwájú ni. Ní àkótán ìà 8 dà bí àlúpàyídà: Ẹsìn mùsùlùmí tí ń ka ara rẹ̀ sí mímọ́ (funfun) àti tuntun (kéwú, ìwé kíkà àti kíkọ, ộlàjú) ni akéwì wáá sọ di àmì ohun àtijộ (ewú) àti àmì ìgbèkùn (ewú eléwú). İlà 8 tilẹ jẹ ìlà 5 ní hain ni. İjìnlẹ ìoộộdárà ni a bá níbí gẹgẹ bí a ti bá a lộhùún. Lékèélékèé gbà ju àlàyé kan lọ. Bí a bá fi ojú odindi ọ̀ọ̣ wò ó, ìtúmọ̀ rẹ̀ ni ẹyẹ funfun. Șùgbộn gírámà èdè Yorùbá fún ni láyè láti le kà á sí àkànpọ ọ̣ọ̣ méjì bákan náà láiluko. Bí a bá sì șe báun, a ó rii pé àwítúnwí $n i$ + èkéé $n i ́$ í șe: Lékèélékèé = ẹni tó ń sábàá máa șèkèé, èèyàn tí ń purọ tà.

Eyọ ộrọ̣ "eyẹ”, tí a fi so lékèélèkèé pọ̀ mọ́ ìmọlle jẹ àmì pàtàkì kan. Șé a ti mọ̀ tệlẹ pé ẹyẹ ni àmì àwọn ìyàmi òṣòròngà, tó bẹẹ tí wọn fi ń pè wộn ní ẹlẹyẹ. Yàtọ fún èyî́, ẹẹ nínú ìlà yí (ìlà 5) dúró fún àmì ìdàgbàsókè (fífò lẹyẹ máa ń fò) gẹgẹ́ bí àwọn fáàbù súúré (ilà 3 ) àti sí (ilà 6) ti lè jẹriìi rẹ̀ àti orúkọ orí. Òpópónà kan náà ni àwọn eyọ ọ̀rọ̀ wọ̀nyí mú tọ̀. Njệ itúmọ "lékèelékèe eye imọ̀le" ni pé èkèe tàbí irọ́ mà ń gòkè fíofío sí i lójojúmọ́. Ẹsẹ Ifá mìràn nínú odù Òtúá kan náà jệiíi ìà yí. Ó ní:

Ìmọ̀le,

Lọjộ wo lẹ ha gbọ́kú Olộrun Ọba?

Èkée yín o

Tí ẹ fi ń gbààwẹ̀.... ${ }^{13}$

Bí èkèé (ẹsìn ìmọ̀le) tí ń gòkè bẹẹ náà ló ń tàn ká gbogbo igun mệrẹ̣ẹin ayé. Ėyí ló tilẹ mú kí ominú máa kọ babaláwo. İtakété àwọn ẹyọ ọ̣ọ̣ sì àti bá pẹ̀lú ọpọtọ àti òrombó fún ni ní ìwọ̀n ìtànkálẹ èkèé lộtùn lósì. Lóooótọ́, si àti bá lòdì sí ara wọn tí a bá fi ojú fọnộlọjì àti ti sẹ̀máńtíkì wò wọ́n:

Sí: àfúnnupè àilóhùn + Fáwẹ́lì iwaájú àpẹnumọ́pè + ohùn òkè.

Bà: $\quad$ àsệnupè olóhùn + Fáwệlì ẹ̀hìn àyanupè + ohùn ìsàlẹ̀.

12 Abimbọla, İjìnlè Ohùn Ẹnu Ifá, Apá 1, o.i. 21.

13 Abimbọla, İjìlè Ohùn Enu Ifá, Apá 4, Òtúá Méjì, ẹsẹ 5, o.i. 87. 
Bẹeè náà ni ọ̀pọ̀tọ́ àti òrombó. Lộnà sẹ̀mántíkì: Igi oko/igi ilé. Lọnà fọnộlọ́jì, ọ̣ọ̣tọ́ ní fáwệlì àșiișítán mẹ́ta (o), kọ́ńsónáńtì àsệnupè àilóhùn méjì (p, t). òrombó ní tirẹ ní fáwẹ̀lì àșeeèsẹtán mẹ́ta $(\mathrm{o})$, kọ́ńsónáńtì olóhùn méjì $(\mathrm{r}, \mathrm{b})$ àti kọ́ńsónáńtì àránmúpè kan $(\mathrm{m})$. àti ọpọotọ́, àti òrombò, igi eléso ni wọ́n. A lè ti ibẹ rò pé igi ẹ̀sìn tuntun ń so, èyí ni pé kò șàiní èèyàn lệhìn. Ẹsẹ Ifá miíràn láti inú Òtúá jẹ́ ni ní han:

Bàbá Mọ̀lé ní òun ni òtútú-ǹtú:

A tú ibejì sínú ilé ńlá

A tú ìbejì sínú oko gbẹnsẹlẹ

Bí wộn ti míbí nílé

Ni wọ́n ḿbí lóko... ${ }^{14}$

Șùgbọ́n bí a bá rántí pé òrombó ní ẹgún àti pé èso rẹ̀ kan, a tún lè rò pé babaláwo fẹé fi ye wa pé lóòótọ ni èsìn ìmọle ń tàn kálẹ ayé, șùgbọn ìtàn-kálè rẹ kò fi bẹe rọrùn ní ilẹ Yorùbá.

Bóyá títệwộgbà tí gbogbo ayé ń tệwọ́ gba ẹ̀sìn mùsùlùmí yî́, bí ó tilẹ jẹ pé òfo àti ọgbọ́n tí kò múná dóko ni Ifá rí nínú rẹ̀, ló mú kí babaláwo fi ara dà á tí kò dìgbò lù ú mọ́:

“O wáá rántí Ifá

Tí àwọn awoo rẹẹe kì fún un

Kò bá wọn jà....

Dípò bẹẹe, tàbí jù bẹẹ̀ lọ pàápàá, akápò fi agídí gbìyànjú láti fi han pé Ifá ni baba ẹ̀sìn ìmọle, àti pé láti inú Ifá ni ẹ̀sìn mùsùlùmí ti súyọ. Ėyí kì bá tí șeé șe bí kò șe pé sítírọ́kíṣọ ẹsẹ Ifá ló fún un ní ànaààn beẹệ. Șé ọ̣ọ̣lọpọ̀ ẹsẹ Ifá ló jẹ mọ ọ̀ràndùn nípa àìríbí àìípọ̀n:

\section{A díá fún Ộrúnmìlà}

Ifá ń sunkún òun ò rọ́mọ bí (İlà 9 àti 10)

Bí a bá fẹeẹ ro èdè tí Ifá fọ̀ yìi sí èdè ọggeẹ̀rì, a lè ka àwọn ìlà méjì wọ̀nyí sí míitì (myth) tí a ó fún ní ìtúmọ lọ báyií: Ộrúnmilà (tó dúró fún gbogbo ọmọ Oòduà: mẹtọ́nímì ìran Yorùbá ni a ka Ifá sí níhìn) ń fí ojú méjéèjì wá àtúnșe, ó fẹeé pìwà dà, para dà: èyí ni pé àwọn baba wa gbà wí pé èsìn àwọn nílò àfikún. A kì șáà gbọ́n tán láyé ni wọ́n ń wí; bẹeẹ ni ọmọdé gbọ́n àgbà gbọ́n ni a fi dá Òtù Ifẹ̀. Njệ Ọ̀rúnmilà fẹẹ bímọ kí ọbộn lè báà máa gorí ọgbọ́n nílée rẹ̣

14 Abimbọla, İjìnlẹ Ohùn Enu Ifá, Apá 3, Òtúá Méjì, ẹsẹ 2, o.i. 92. 
(àní ní ilẹ Yorùbá). Ibi tó ti ń janpata àti-tún-ẹni-bí yìí (Wộn ní ó rúbọ... ó sì rú u) ni ẹ̀sìn ìmàle ti jẹ jáde kúrò láti inú ẹsìn àdáyébá (Ó bí Gánḿbí...abl.). Ifá wáá sọ ara rẹ̀ di ìbẹ̀rẹ àti òpin. Ògúndá Méjì kò ha ti kọ́ wa pé:

Ifá ló lòní

Ifá ló lọ̀la,

Ifá ló lộtúnla pẹ̀lú rẹ̀;

Ộrúnmilá ló nijọ́ mẹ́rèệrin Òòsà dááyé? ${ }^{15}$

Gbogbo rẹ̀ wáá já sí òkìrìì̀ì gẹgẹe bí míitì òsùmmàrè. Șé ejò afirùbọnu ni àmì òșùmàrè: àti orí ìrù ejò, kò sí èyí tí kò șe pàtàkì níbẹ̀. Yálà ẹnu ń pọ ì̀ù ni $\mathrm{o}$, tàbí ó ń gbé e mì ni o, kò sí èyí tí a yàn níbẹ tí kò mú ọgoọ́n dání. Bẹẹe gẹeé ni ìbáșe láàrin Ifá àti ẹ̀sìn ìmàle. İdí nìyí tí a fí ń gbọ́ pé.

Ó wáá rántí Ifá

Tí àwọn awoo rẹẹe kì fún un,

Kò bá wọn jà.

Bí a bá fi ọwộ ộtún na ọmọ ẹni, tòsì kọ la fi ń fàá mộra bí? A fi àwọn àyọlò láti inú òwe wọ̀nyí dábàá irú àbáṣepọ̀ tó ń bẹ láàrin Ifá àti ìmàle:

1. Ayé la bá'Fá, Ayé la bá'Mọ̀le, Ọsán gangan nìgbàgbọ́ wọlé.

2. Ifá ó sunlé, Ààfáà ó sùnta, İgbàgbó kò rí ibi sùn mọ́, ó suntẹ́.

Bí a bá yọ àwọn ìgbàgbọ́ kúrò lọ́wọọ̣, ìtúmọ àwọn òwe méjéèjì wọnyí bá ohun tí a ti ń sọ wá mu: èyí ni pé lórí àkàsọ tí a to àwọn èsìn tí Yorùbá mọ sí, òkè ténté ni Ifá wà. Ìmọle ń pọ̣ṣẹ̣ẹ lệhìn Ifá ni, ó sì sún mộ ọ pẹ́kípẹ́kí. Șùgbộn bí ó tilẹ jẹ pé hanha báyií ni ộpọ̀lọ fi ju aláàmù lọ, síbẹ iyàtộ ń bẹ láàrin wọn mànà. Ộọ̀ kò kún ní ibi pé kí á ní àwọn ẹ̀sìn méjì bá ara wọn tan tàbí pé wọ́n tilẹ dà bí baba (Ifá) àti ọmọ (mùsùlùmí). A kò gbọdọ gbàgbé pé ara èkíní kò fi bẹeè yọ sí ara èkejì. Bí ọmọ ìta tàbí ọmọ àlè ni Gánḿbí, Kàlitú àti Dáúdù rí lójú Ọ̀rúnmílà. Wọn kò șe déédé, bẹẹ ni wọn kò sì hùwà tó tọ̀nà lójú baba wọn. Míitì àigbọràn (Ìlà 35 dé 46) wá kún míitì òsùmàrè. A ti rí iru mítì àìbọràn bẹeẹ nínú Odú İwòrì Méjì, ní ibi tí ọ̀kan nínú àwọn ọmọ Ộúnmílà tí à ń

15 Abimbọla, İjìnlè Ohùn Ẹnu Ifá, Apá 1, Ògúndá Méjì, ẹṣe 2, 0.i. 101. 
pé ní ìgbà-tí-mo-bímọ-tán-ni-wọ́n-ńfọ̀wọ̀-ọmọọ-mi-wọ̀-mi, kọ̀ láti tẹrí ba fún baba rẹ̀. Nínú Òtúa Méji níbí, gẹgẹ̣ bí ti İwòrì Méjì lọ́hún, irú ọ̀ràn kan náà ló jẹ jáde níbi à̀gbọràn yí: Pátápirá rẹ̀ ni ìdàrú àti èérí. Nínú İwòrì Méjì, Ifá relé Olókun kò dé mọ, gbogbo nǹkan wáá dà rú nílé aye. ${ }^{16}$ Nínú Òtúa Méjì ìdàrú àti ìwà àìmọ náà ló gbẹ̀hìn ọ̀ràn.

Lóòótọ́, láti inú Ifá ni ẹ̀sìn ìmọ̀le ti súyọ. Șùgbộn nígbà tí yóò ti ibẹ jáde ńkộ, șe ni a și Ifá mọ̀. Àșírí àti awo tí Ifá fi lé àwọn ọmọ mẹtẹ̣ẹta lộwọ́ (Ó kọ́ wọn ní dídá awo abl.) ha ńkộ? Àbájáde rẹ̀ yàtọ gidigidi sí ti ojúlówó lộnà tí kò sunwọ̀n. Nítorí pé àșệhìnwá àșệhìnbọ̀ ị̀úyọ ẹ̀sìn mùsùlùmí láti inú Ifá ni pé: ẹsìn tí a kà sí ìmọ àti ìrànlộwọ́ ọmọ aráyé láyé àtijộ wáá di ọgbọ́n àșejẹun àti àkàsọ fún ìmọ̀tara-ẹninìkan:

Bẹẹ̣ ni àwọn ọmọ náà șe

Tí wọn fi ń dárà gbogbo

Kódà ìwà wọ̀bìa tí a ń wí yî́ tún hàn ju èyí lọ nínú ẹsẹ Odù Òtúá mìiràn. Ẹ gbọ́:

Jingiri níi fi gbogbo araá jókòó,

A dáá fún Baba Mọ̀le, abẹ̀wù gẹreèjẹ̀,

Tí yóó fi ayé gbogbo sộfẹ je

Wọn ní ó káalè,

Ebọ ni kí ó șe.

İgbà tó rúbọ tán,

Tí ayé yẹ ẹ tán

Ó ní ơfé ni n ó maa jệ ${ }^{17}$

Lẹ́hìn náà ẹ̀wẹ̀, kò tún sí ọ̀wọ̀ lára ẹ̀sìn mọ́ ní ìwọ̀n ìgbà tí kò sí àșírí àti awo mọ́. Nǹkan awo ti wáá di nǹkan gbangba dẹkùn kedere bẹ ẹ wo, nǹkan ìnáwó, nǹkan ọjà, ní ọ̣ọ̀ kan, ohun tí a le rà. Awo ti kúrò ní ìgbàlẹ̣:

Àwọn ọmọ mẹ́tẹẹta yì ó lọ síbẹ̀...

Wọn á ránńṣẹ pè wộn.

Láifepo bọọ̣, àbájáde ẹ̀sìn mùsùlùmí láti inú Ifá ti sọ òye, aájò, ìmọ àti ọgbọ́n fún ìlọsíwájú ènìyàn tí à ń pè ní ìwúlò tàbí iṣẹ ẹ̀sìn di iṣẹ lásán, láìí ẹsìn:

16 Abimbọla, İjìnlẹ Ohùn Ẹnu Ifá, Apá 1, İwòrì Méjì, ẹsẹ 1, o.i. 43-47.

17 Abimbọla, İjinlẹ Ohùn Ẹnu Ifá, Apá 3, Òtúá Méjì, o.i. 93. 
Wọ́n wá mú un bí iṣẹ (ìlà 54).

Ėyí wáá dà bí ìgbà tí páńsá tí a fi há sí òkè já lulẹ̣, tàbí kí ìàwọ̀ já láti ojú sánmà. Bóyá jíjá tí ohun tí a gbé ga jù lọ (Ifá) já ló jệ kí babaláwo lè ronú ilé ayé, tí ó sì kọ ẹ̀hìn sí ọ̀run láìsí ìrọ́kẹ̀kẹ̀, ni àbáyộí ẹsẹ Ifá rẹ̀. Àbáyộí ẹsẹ Ifá yìi tilè sunwọ̀n púpọ̀. Ó sì tún kọ́ ni lọgbộn pé kò sí ohun tó ju ènìyàn lọ lábẹ́ ayé. Ó fệrẹeé dà bí ẹni pé ohùun "wi" (lẹtà w) ni babaláwo fi ń lùlù níbí. A sì gbọ́ ìró $\mathrm{W}$ yìi gẹgẹ̣bí gboùngboùn ìlù kan tí a ti gbọ́ rí ní ìbẹ̀rẹ ẹsẹ Òtúa yií. Ėè̀mẹsàán ni a lo ohùn $\mathrm{W}$ nínú ilà mẹ́rin ìdá keje tí í șe àbáyọrí ẹsẹ Ifáa wa yìí, (İlà 88-91). Báyìi ni wọ́n sì pín ara wọn sí nínú ìlà mẹerẹệin wọnnì:

Ìlà àkọ́kọ́: $\quad 2 \mathrm{~W}$

Ìlà kèjì: $\quad 3 \mathrm{~W}$

Ìlà ẹ̀kẹta: $\quad 2 \mathrm{~W}$

Ìlà ẹkẹrin $2 \mathrm{~W}$.

Láàrín àwọn fáwệlì tó tẹ̀lé ohùn $\mathrm{W}$ ní ìparí ẹsẹ yî́, àwọn fáwẹ̀lì àyanupè ló wộpọ̀. Ėyí lòdì sí ohun tó șẹlẹ ní ibẹ̀rẹ ẹsẹ Ifá yîi níbi tí a rí kìkìdá U tí í șe àkộkọ́ nínú àwọn fáwẹ̀lì àpẹnumộpè. Kín ni ìúmọ̀ tí a ha lè dábàá fún ìyàtọ láàrin lílò fáwẹ̀lì ní ibẹ̀rẹ àti ní ikádií ẹsẹ Ifá yîi. Ó lè jẹ́ pé ìyàtọ yìi ń tọ́ka sí ìrètí àti ìsípayá sí ọ̀ràn ayé àti ìlọsíwájú ènìyàn, yàtọ fún ohun ìsáátá tí a gbọ́ ní ỉbẹ̀rẹ. Bóyá irú ètò ojú-òdì tí ń bẹ nínú sẹ̀mántíìì àwọn ìdá 1 àti 7 ló tún hàn jáde nínú fonộlọjì tí í șe aṣo ìbora rẹ̀: U nìkan nínú ìdá àkọ́kọ́ kí á fi ta kò $\underline{\boldsymbol{o}}$ méjì, $\mathbf{o}$ kan àti $\underline{\boldsymbol{a}}$ mệà nínú ìdá keje. İtúmọ ètò ojú-òdì yí ni pé ní ìbẹrẹ ẹsẹ Ifá (ìdá 1) èdè mùsùlùmí (wútùwútù) kò yé akápò; ó dà bí ẹnà tàbí èdè awo tí kò le hàn sí ọgbẹ̀rì tàbí ẹnikẹni. Èyí ló fa lílo ògédé $U$, fáwệlì àpẹnumộpè. Sùgbọ́n nínú ìparí ẹsẹ wàyí o, ìdá keje ti tan ìmộlẹ sí awo, àșírí àti ìúmọ èsìn mùsùlùmí àti pàápàa èsìnkẹsìn. İdí nìyí tí fáwélì tó yè koro (àyanupè) șe wọpọ.

Eyọ ọ̀ọ̣ àwa, tí a rí nínú ilà mẹerẹệrin àti lẹẹemẹta ní ìbẹrẹ̣ ilà șe pàtàkì ní ikádií ẹse yî́. Ó sì ń bèrè fún itúmọ̀. Àwa níbí já sí 'àwa tikárawa', (èyí ni pé àwọn onífá) pẹ̀lú ẹyin ìmọ̀le àti àwọn ẹ̀sìn míràn tí a mọ̀ tàbí tí yóò wáyé níjọ iwájú. Ėé ha ti șe tí babaláwo wá ń so àwọn ẹsìn wọ̀nyí pọ nígbà tí ó ti fi wộn ta ko ara wọn ní ỉbẹrẹe? A rò pé bóyá ẹmí ìfệ tàbí ti ìfaradà, tàbí méjèèjì pọ ló gùn ún. İfaradà nítorí ẹsìn tuntun șá ń fẹsẹ̀ rinlẹ bí ó ti lẹ̀ jẹ pé kò wú onílàákàyè lórí tó ẹsìn àdáyébá tó bẹẹ tí kò tọ́ kí á kó o máyà (ká fệwù àlàárì fọnkun àmódi). Ėmí îẹe àti ìtẹ́wộgbà ní ìwọ̀n ìgbà tí babaláwo ní ìkadî́ ọ̀rọ̀ rẹ̀ ti wáá já oggbọ́n èké tó so gbogbo àwọn ẹ̀sìn pọ̀: òun ni ìẹe sí nǹkan ìsúra ayé yìi (owó, ọmọ, àtubọ̀tán ayé). A fi bẹẹe yé ni pé òpè ènìàn ló lè tìtorí ẹ̀sìn bá ọmọ ẹìkejì rẹ̀ ja àjàkú, nítorí "ẹnu là ń bọ”. Ifá náà ló sọ báyî̀ pé: 
Àteégún, àtòòsàà,

Lóòótọ lajé jù wọ́n lọ,

Ajé jù wọ́n lọ lóòótọ. ${ }^{18}$

Àwọn ìlà 89 dé 91 tẹ́ ẹní fáwẹ̀lì mẹ́ta: $o, o$ àti $a$. Ẹẹ̀mẹta ni a sì lo ộkọoọ̀kan wọn láti àfikún fáàbù wá lọ. A ó sì șe àkíyèsí pé a kò șàdéédé lo àwọn orúkọ mẹ́ta tíi șe àfikún fáàbù wá, tí wọn sì jẹ kókó ọ̣ọ̣ inú ìkadî́ ẹsẹ yî̀. A tò wọ́n sórí àkàsọ láti ilẹ dé òkè bí wọn șe ń tẹ lé ara wọn mà ni. Pẹlúpẹlú bí a bá fi ojú fonọ́lọjì wò ó, bẹe gégé ni àwọn fáwẹlì ń șí sí i bí a șe ń gòkè sí i lórí àkàsọ yẹn. $O$ ni àtètèkàn, $O$ ní a fi tẹ̀ ẹ, $a$ lé té lórí gbogbo wọn:

\author{
$o \ldots o \ldots a$ \\ owó \\ ọmọ \\ àtubọ̀tán ayé
}

Ó tilè jọ ni lójú pé a rí palíndóòmù (palindrome) méjì tó sunwọ̀n jọọ láàrín ìlà mẹ́rin wọ̀nyí. Lẹệkan sí $\mathrm{i}$, șe ni àwọn palíńdóòmù náà tún tẹ̀ lé ara wọn lórí àkàsọ̀; nítorí pé "owó" kì í șe palíńdóòmù kíkún, alákùdé ni: a kò le kà á láti ọoọ ộtún gẹegẹ bí a ti ń kà á láti ọwọ òsí nítorí ohun yàtọ lórí àwọn fáwệlì $O$ méjéèjì Șùgbọ́n ojúlówó palíńdóòmù ni “omọ”. A le kà á bákan náà láti ọwọ òtún àti òsì. Ó sì férẹẹ jọ pé kíkún tí palíńdóòmù "omọ" kún fi hàn wá pé ni èrò Yorùbá láye ijọ́un, ọmọ ju owó lọ ni.

Fáàbù tán àti orúkọ ayé tí babaláwo fi ti ẹsẹ Ifá rẹ̀ yí kò mú ìyanu wá fún ni. Ayé la mọ̀, ọ̀run lojú wa kò tó. Ayé sì ni ìbẹ̀rẹ àti òpin àti òsùnwọn ohun gbogbo. Ohunkóhun tí ó wù kí èèyàn fi pọ́n ara rẹ lójú láti ibi ẹ̀sìn, òtúa (asán, òtúbántệ) ni. Ó mú ni rántí òótọ ọ̀rọ̀ tí ọjọ̣gbộn Faransé kan, ọggeẹni Leprince Ringuet, sọ báyî́: "Ohun tí ewì né lépa kò ju pé kí ó gbé ayé mì lo". ${ }^{19}$

A gbà pé àwa Yorùbá òde òní kọ́ ní akápò ní lọ́kàn nígbà tó ki Ifá yî́, síbẹ̀ ẹ̀kọ́ tí a lè kórè níbẹ kúrò níba. Ìkìlọ pé kí a má maa ti ibi ìyàtọ nípa ìgbàgbọ́ tàbí èrò kóriíra ara wa wúlò púpọ̀ ní ayé òní ju ayé ijộn lọ. Ifá náà kọ́ ló ní

18 Abimbọla, İjìnlẹ Ohùn Enu Ifá, Apá 1, Ìká Méjì, ẹsẹ 3, p 120.

19 Wộn ní: A día fún Ayélẹgún,

Yóò gbédèe rẹ̀ sọnù,

Gbogbo aye ní ọ́ mọọ bá a wá a kiri. (Abimbọla, Àwọn Omo Odù, Àpólà Ogbè,

Òkànrìnsodè, Ẹsẹ Ẹ̀ẹta, 263).

Irú itúmọ̀ tí a fún un lábẹe orí ọ̀ọ̣ yìi șe dédé pẹ̀lú ohun tí Wande Abimbọla sọ nínú: "Ifá Divination Poetry and the Coming of Islam to Yorùbáland: A Preliminary Investigation nínú Pan African Journal Volume IV, No. 4, New York, fall 1971. Ojú ewé 440 dé 452 . Bẹẹ sì ni, "Mọ̀rìwò ọ̀pẹ ò wí fún raa wọn tẹ́lẹ

Tí wọ́n fi ńyọ".

Ifá náà ló wí báun. 
"ọràn isinyí won ò tó 'jà"17 bí ìmọ̀ràn míràn tí a tún lè mú lò ní ayé òní láti ẹsẹ Ifá yií ni oggbọ́n pé kí ohun àlùmọọ̣nì wa ní òpópónà àșà tàbí èdè wa máa jọ wá lójú, kí a sì yé é máa "garùn wọlá ọlọlá". ${ }^{18}$

Ẹwà ẹsẹ Ifá yî́ kò fi gbogbo ìgbà fașo bora. Ộpọ̀lọpọ̀ iṣẹ ọnà tí babaláwo fi șe ẹse ọ̀hún lộṣọộ ló hàn. Síbẹsíbẹe túláàsì ni aṣọ ìbora, a gbọ́dọ gbìyànjú kí á sàlàyé diẹe nípa ìdí rẹ̀ tí a fi ni ewì kan dára bí ó ti wù kí ó sunwọ̀n lójú wa tó. Ìdí nìyí tí a fi ìrànlộwộ lìngúísítiìì hú diẹe nínú ẹwà yí jáde láti ibi àjà mẹta tí a gbàgbọ́ pé èdè ní: fonọolọjìi, gírámà àti sẹmmántíikì. A kò sì fi beẹẹ gbàgbé pé ẹwà kì í șe ohun tí a lè là sí wẹ́wẹ́ kí á tẹ ẹ sórí àtẹ. Ộkan șoṣo bí orógbó ni. İwọ̀n ni a sì ní láti polówó ọbẹ tó dùn mọ. İdí nìyí tí a fi ń șẹ́ oyún ọ̀rọ̀ tí a ní sínú tí a fẹeé sọ lórí ẹsẹ Ifá yîi nígbà míràn.

Dájúdájú, ó lòdì sí àșà àti ìșe, pé kí á fi ọ̀ọ̣ bí ìwàásù tàbí ìsúre kádíi èrò ẹni, bí a bá ń șe ìwadií tàbí iṣẹ onímọ bí irú eléyií lórí lítíréṣọ. Bí a bá yapa sí irú àșà àwọn ọjọ̣gbộn yî́ a ń tọrọ gááfáà o. Șùgbọon kì í șe pé a șáko lọ ni. İdí abájọ sì ń bẹ. A rò pé bí a kò bá șe bẹẹè, Ifá yóò hun wá. Ẹkọ́ ńlá tí a gbộdọ ti ibi kíka àwọn ewì àdáyébá kọ́ ni ìrẹ̀lẹ. Nítorí pé nípa kí á fi ọgbọ́n, òye, ìmọ̀ àti ẹwà hun ara wọn pọ̀ nínú èdè kí a sì fi bẹẹ gbé awẹ́lệà ewì kalệ, àwọn baba wa ni ará iwájú, àwa ni èrò ẹ̀hìn. Șùgbọ́n lónií yìi tí a ti di "Ayélẹgún" ńkóo ${ }^{19}$ Òwèrè ló kù tí a ń jà. Àwọn akéwì òde òní mìiràn kò tilẹ fi ara balè kọ ọgbọn àdáyébá tí baba wa fi ń to ewì wọn àti iṣé ọnà tí wọn ń șe sí wọn lára kí wọn tóò hán kálámù wọn pé àwọn $n$ kọ ewì. Bẹe sì ni ìrẹlẹ ni ìpẹkun èkọ. A kò wí pé kí a máa yọ ètò tuntun jáde nípa ewì kíkọ lóde òní. Ń dáa o. Èrò jọ-mi-jọ-mí jìnà sí ọkàn wa. A sì tilẹ gbàgbọ pẹ̀lú pé ìwọ̀n là á jọ baba ẹní mọ. Șùgbọ́n ògúlùǹtu náà là á fi í kộlé tó lágbára. A kò le dábàá ètò titun nípa ewì kíkọ láìmọ òfin tó de ewì fífọ àwọn baba wa. Nítorí bẹẹ nínú ẹ̣oọ nípa Ifá, iwì, ègè, ijálá, ẹ̀ẹ̣, alámọ̀, rárà, olele...abl., ni ìgbàlà ewìiwa wà o. Kí á kọ́ ẹ̀kọ́ nípa rẹ̀ kò sì tó kí àwa alára máa pè wộn. Ėyí șe pàtàkì púpọ̀ nítorí ogunlọgọ̣ “ọmộwé” òde òní ló ń rò pé kò sí ọlàjú nípa pé kí akọwé máa sun rárà. Wọ́n ti wáá pín ayé sí ọwọ méjì: kíkọ ni talákọwé, pípè ni tagbe. Irú èrò àti ìwà báyî́ kò mọgbọ́n dání pẹẹpẹe. Bí a kò bá sì fi ọwọ wọn bọlẹ, kí á yárá lọ mọ pé ọpọlọpọ ewì tí a ń kọ lónìi tí à ń pọ́n tí a sì ń rọ kẹkẹ̀ sí wọnyí kò ní ní èmí gígùn. Ó mú mi rántí orin àwọn oníjàálá kan tó lọ báyií:
Odẹ:
E ẹ́ gberin, à bẹ ẹ̀ gberin
À̀ọn elégbè rẹ̀:
Bí ọ bá pòșé a ò níí gbè.

\section{Ộúnmìlà afèdèfẹyọ̣, Ẹlà İsòdè kò níi jẹ́ kí á fi èdè Yorùbá pòșé $0 .{ }^{20}$}

20 Mo dúpẹ lộwọ́ 'Sopé Oyèláràn, kòfệsọ̀ Ayọ̀ Bámgbóṣé àti awo 'Wande Abimbọlá fún ìmọ̀ràn àti ìrànlộwọ́ tí wộn fún mi. Gbogbo àléébù àti èérí inú iṣẹ yìí, tèmi ni. Mo si fi sosùn, mo fi para. İdákúdàá lọmọdéé dá'Fá o. A ó rí i pé a yá àwọn ọ̣ọ̣ mélòó kan láti inú èdè Òyìnbó. Kò sí láburú ní ibi pé kí á máa lo àwọn ọ̣ọ̣ bíi fonộlọjì tàbí lítíréṣọo, tó ti wọ 


\section{Àfikún I}

a. Zeugma: Nínú lítíréṣọ àwọn òyìnbó, ìbáà șe "Gẹẹèì, Faransé, Pàyáàn tàbí Rọsíà, ohun tí a ń pè ní zeugma ni àfẹ́kù ẹọ ọ̀ọ̣ kan (pàápàá jùlọ ộọ̀ ìse tàbí èyán ọ̀rọ̀) nínú ìlà méjì tàbí jù bẹẹ lọ níbi tí a ń retí rẹ̀ nítorí pé ó ń bẹ nínú ìlà iwájú tí a sì mọ dájúdájú pé eléyìi bá àwọn ìlà wọ̀nyí dọ́gba.

b. Palindrome: Eyọ ợọ tí a le kà bákan náà yálà láti òsì dé ọtún gẹgé bí a ti ń ka ìwé, tàbí láti ọtún dé òsì, gégẹ bí wọ́n ti ń ka kéwú ni àwọn Òyìnbó ń pè ní palindrome. Àpẹẹe láti mú èdè Yorùbá.

Òwọ, òwò, $\quad$ olọ.

Òtúá Méjì

Àfikún II

Wútùwútù yáákí;

Wútùwútù yámbèlé; ${ }^{21}$

Ká súré pátápirá,

Ká fẹ̀wù àlàárì fọnkun àmódi;

5.

Lékèélékèé, ẹyẹ ìmọle, ${ }^{22}$

Bó bá șí lórí ọ̣pọ̀tọ́,

A bà sórí òrom̀bó,

A máa fi gbogbo ara kéwú eléwú kiri;

A díá fún Ộrúnmìlà,

inú ọ̀pọ̀lọpọ̀ èdè àgbáyé. A sì rò pé ìdí rẹ̀ hàn sí gbogbo wa. Șùgbọ́n a gbàgbọ́ pé àwọn ọ̀rọ̀ míràn wà tí a yá lò, tí a sì rò pé bí a bá ronú jinlệ, a lè rí ìtumọ̀ wọn tàbí ọ̣ọ̣ tí yóò dúró fún wọn ní èdè Yorùbá. Àwọn wọ̀nyí ni àwọn ọ̀ọ̣ bíi palíndóòmù, sẹgímà...abl., tí a fi ẹdà wọn ní èdè Gẹẹesì sí ẹgbẹ́ wọn nínú àdìtú yìi. Àwọn wọ̀nyí ni a lè sọ pé a yá lò lóóótọ, èyí ni pé a ó dàá wọn padà sínú èdè wọn níjọ iwájú bí àwa náà bá wáá rí ọ̣ọ̣ tí a ó fi rộpò wọn nínú èdè Yorùbá. Àwọn ọ̀ọ̀ míràn wà tí a kò șiyèméjì láti túmọ wọn. Gẹegé bí àpẹerẹ, open vowel tàbí fricative tí a pè ní fáwẹlì àyanupè àti àfúnnupè. Șùgbộn ní gbogbo ìgbà àti fún gbogbo ộọ̀ kọ́ ni èèyàn le dá ara rẹ̀ lójú báun. Ộpọ̀lọpọ ọ̀oọ làwa náà lò tí kò sí tíi tẹ́ wa lộrùn. Àti pé, pàápàá jùlọ, a gbàgbọ pé ờràn lílo àwọn ọ̀rọ Yorùbá gẹegé bí irinṣẹ láti fi kọ èrò ìjìnlẹ lórí èdè àti lítíréșọ wa ní èdè Yorùbá kì í șe ộràn ẹnikan șoṣo. Nítorí èyí ni a șe ń ké pè yín pé kí ẹ bá ni dá sí i. E Eá ni wo ọ̀ràn yí nítorí ojú kan kì rọ́ràn ni wộn wí. Wàyí $\mathrm{o}$, àdúrò nijó. Nínú lílo èdè wa fún àròkọ ișé onímọ̀ èdè náà ni a ó ti máa kó àwọn ộộ tí a nílò jọ diệdiệ. A kò lè dúró kí wòlíi kan tàbí ẹnikẹni rọjò wọn sí wa lộkàn láti òkè ọ̀run. Șe ló sì yẹ kí á ronú jinlẹ kí á sì jíròrò lórí ilànà tí a ó tọ kí a tóó bẹ̀rẹ síi șẹe àwọn ọ̣ọ̣ tí a nílò. Ėdè wa náà ni yóò wáá șe asẹ tí yóó yan àwọn tó wúlò nínú gbogbo ọ̀rọ̀ tí a ń șẹ́. Kí á șá màá fọ èèbó gbàgbé àfira náà ni pàtàkì.

21 Wútùwútù yááki: wútùwútù yámbèlé; à ń fi eléyî́ sín àwọn ìmọ̀le jẹ nípa bí kéwúu wọn ti ń dún létí ẹni tí kò gbọ́ kéwú.

22 Lékèélékèé, eyẹ ìmọle: àwọn ìmọ̀le fệràn aṣọ funfun bí aṣọ ara ẹyẹ tí ń jệ lékèélékèé. 
10. Ifá ńsunkún òun ò rọmọ bí.

Wộn ní ẹbọ ní ó wáá rú,

Ó sì rú u,

Wộn ní ó réku méjì olùwéré;

Kò rẹ́ja méjì abìwẹggbàdà;

$15 . \quad$ Obídie méjì abẹ̀dọ lùkẹlùkẹ́;

Ewúrẹ méjì abàmú rẹdẹrẹdẹ;

Einlá méjì tó fîwo șòsùuá.

Gbogbo rẹ̀ náà ló rú.

İgbá tí Ộrúnmìlà ó kọọ̣ bí,

20. Ó bí Gánmibí. ${ }^{23}$

İgbà tí ó tùún bí,

Ó bí Kàlitú. ${ }^{24}$

İgbà tí ó tùún bí,

Ó bí Dáúdù, ${ }^{25}$

25. Èyí tíi sọmọ ìẹ̀yìn wọn lénje lénjje.

Ikú kò pa wọ́n,

Àrùn kò șe wọ́n.

İgbà tí wọ́n dàgbà tán,

Ọrúnmilà kọ́ wọn ní dídá ọwọ́,

$30 . \quad$ Wọ́n mọ̀ ộn dá

Ó kọ́ wọn létìtẹ alẹ̣,

Wọ́n mọ̀ ộn tẹ̀.

Ó kọ́ wọn ní ọ̀karara ẹbọ,

Wộn mọ ộn há.

$35 . \quad$ Nígbà tó dọọo kan,

Ni wọ́n bá ré agbádáa babaa wọn,

Wọ́n ré gèlè ìyáa wọn;

Wọ́n wọ agbádá náà,

Wộn sì wé gèlè náà sórí bàntùtù,

23 Gánḿbí: Orúkọ ọmọ ìmọ̀le.

24 Kàlìtú: Orúkọ ọmọ ìmọ̀le.

25 Dáúdù: orúkọ ọmọ ìmọ̀le ni èyí náà. 
40. wộn na igi mệrin sílẹ níbùú-níbùú. ${ }^{26}$

Wọ́n wáá kó sí ààrin àwọn igi náà,

Wộn ń șẹnu wújẹewújẹe,

Wọ́n ń foríí kanlẹ,

Wọ́n ń dìde.

45.

Wọ́n ń kúnlẹ̀,

Wọ́n sì ń nàró.

Bàbáa wọ́n șá ń, wò wọ́n ni.

Wộn ń șe bẹẹ lẹeẹmaàrúnmárùún lójoojúmọ́.

Ó wáá rántí Ifá

50.51 àwọn awoo rẹẹe kì fún un,

Kò bá wọn jà.

Kẹeẹ̀kẹẹ kiní yî́ ń wọ̀ wọ́n lára.

İgbà tó yá,

Wọ́n wáá mú un bí iṣẹe.

55.

Ó di wí pé

Bí ẹnikan ba ń sọ ọmọ lórúkọ,

Àwọn ọmọ mẹtẹẹta yìi ó lọ síbẹ̀.

Bí òkú kú fún ẹnìan,

Wọ́n á ránńṣẹ pè wộn.

60. Bẹẹ̀ ni àwọn ọmọ náà ṣe

Tí wọn fi ń dárà gbogbo.

İgbà tí wọn dàgbà tán,

Tí àwọn náà bímọ.

Bẹẹ náà ni àwọn ọmọ wọn ń șe

65. Ijó ni wọ́n ń jó,

Ayọ̀ ni wọ́n ń yọ̀;

Wộn ní bẹẹ̀ gẹeé

Ni awo àwọn ń șẹnu rereé pefá.

Wútùwútù yáákí;

70. Wútùwútù yámbèlé;

Ká súre pátápirá;

26 Wọ́n na igi mẹrin sílẹ níbùú-níbùu: Àwọn Ìmọ̀le a máa na igi sílẹ bàyìi láti fi șe mọ́sáláạsí. 
Ká fệwù àlàárì fọnkun àmódi;

Lékèélékèé, eyẹ ìmọ̀le,

Bó bá șí lórí ọ̣pọtộ,

75.

A bà sórí òrombó,

A máa fi gbogbo ara kéwú eléwú kiri;

A díá fún Ộrúnmìlà,

Ifá ń sunkún òun ò rọ́mọ bí.

Wộn ní ó káakí Mọlẹ,

$80 . \quad \mathrm{O}$ jàre,

Ebọ ní ó șe.

Ó gbọ́ rírú ẹbọ,

Ó rú.

Ó gbọ́ èrù àtùkèșù,

$85 . \quad$ Ó tù.

Ó gbọ ikarara,

Ẹọ́ ha fúnn un.

Ire mẹ́ta làwá ń wá:

Àwá ń wówó o,

90.9 àwá ń wọmọ;

Àwá ń wá àtubọ̀tán ayé. 